\title{
Productive performance of Nellore steers on rotational grazing on Marandu grass and Convert HD 364 grass
}

\section{Desempenho produtivo de novilhos Nelore em pastejo rotativo de capim Marandu e capim Convert HD364}

\author{
André Felipe Borges Krinchev ${ }^{1 *}$; Valter Harry Bumbieris Junior ${ }^{2}$; \\ José Renato Silva Gonçalves; ; Laísse Garcia Lima³; Ana Maria Bridi²; \\ Edson Luis de Azambuja Ribeiro ${ }^{2}$
}

\section{Resumo}

O presente trabalho teve como objetivo, avaliar o efeito da Brachiaria spp. cv. Mulato II (Convert) sobre o desempenho, qualidade de carne e características de carcaça de novilhos Nelore castrados, na fase de recria e terminação, em sistema de pastejo rotacionado em comparação com a Brachiaria brizantha $\mathrm{cv}$. Marandu, nas mesmas condições. A área experimental era composta por 40 hectares, divididos em dois tratamentos: Marandu e Convert, com 20 hectares cada. Cada tratamento possuía quatro repetições e cada repetição era um módulo composto por cinco piquetes de um hectare cada. Os animais foram manejados de acordo com a oferta de matéria seca de lâminas foliares $(6,19 \%$ do peso vivo), em pastejo rotativo, com 7 dias de ocupação e 28 dias de descanso. Foram utilizados 10 animais em cada repetição (testers), além de animais reguladores, quando necessário. Para análises de desempenho, foram utilizados os 10 animais de cada repetição, enquanto para análises de carcaça e carne utilizouse seis animais por repetição. Foram avaliadas caracteristicas de produção e bromatológicas das duas gramíneas. O delineamento experimental foi inteiramente casualisado com dois tratamentos e quatro repetições, os dados foram submetidos à análise de variância utilizando o programa estátistico R. Os animais alimentados em pastagens estabelecidas com capim Convert foram superiores em relação aos alimentados em pastagens estabelecidas com capim Marandu, tendo maior ganho médio diário durante o período experimental $(0,682 \mathrm{~kg} \mathrm{x} \mathrm{0,605} \mathrm{kg),} \mathrm{peso} \mathrm{ao} \mathrm{abate}(470,45 \mathrm{~kg}$ x 451,43 kg), peso de carcaça quente $(239,93 \mathrm{~kg} \times 232,36 \mathrm{~kg})$. O trabalho também mostrou a possibilidade de terminação de novilhos castrados jovens (até 30 meses) e com a espessura de gordura subcutânea exigida pela indústria $(3 \mathrm{~mm})$ em ambas pastagens utilizadas.

Palavras-chave: Bovinos de corte. Carcaça. Forragem. Ganho de peso. Qualidade de carne.

\footnotetext{
Abstract

The objective of this study was to evaluate the effect of Brachiaria spp. Cv. Mulato II (Convert) on performance, meat quality and carcass characteristics of castrated Nellore steers in the growing and finishing phases, in rotational grazing system, compared to Brachiaria brizantha $\mathrm{cv}$. Marandu, under the same conditions. The experimental area was divided into two treatments: Marandu and Convert

1 Discente, Programa de Pós-Graduação em Ciência Animal, Universidade Estadual de Londrina, UEL, Londrina, PR, Brasil. E-mail: andre_krinchev@hotmail.com

2 Profs. Drs., Departamento de Zootecnia, UEL, Londrina, PR, Brasil. E-mail: jrbumbieris@uel.br; ambridi@uel.br; elar@uel.br

3 Pesquisador, Estação Experimental Agrozootécnica Hildegard Georgina Von Pritzelwitz, Fazenda Figueira, Londrina, PR, Brasil. E-mail: fazendafigueira@uol.com.br

* Author for correspondence
} 
with 20 hectares each, splited in four replications per treatment, composed of five paddocks of one hectare each. Animals were managed based on the availability of leaf blade dry matter $(6.19 \%$ body weight) in rotational grazing with 7 days of occupation and 28 days of rest. Ten animals were used in each replicate (testers), as well as regulatory animals whenever necessary. Animals were managed based on the availability of leaf blade dry matter (6.19\% body weight) in rotational grazing with 7 days of occupation and 28 days of rest. Ten animals were used in each replicate (testers), as well as regulatory animals whenever necessary. For performance analysis, 10 animals of each replicate were used, while for carcass and meat analyses, only six of each replicate. Production and chemial characteristics of the two grasses were evaluated. The experimental design was completely randomized with two treatments and four replicates; data were tested by analysis of variance using the $\mathrm{R}$ software. Animals fed on Convert grass were superior than those fed on Marandu grass, with higher average daily gain $(0.682 \mathrm{~kg}$ vs. $0.605 \mathrm{~kg}$ ), slaughter weight ( $470.45 \mathrm{~kg}$ vs. $451.43 \mathrm{~kg})$, hot carcass weight $(239.93 \mathrm{~kg}$ vs. $232.36 \mathrm{~kg})$. The study also showed the possibility of finishing castrated young steers (up to 30 months) and with subcutaneous fat thickness required by industry $(3 \mathrm{~mm})$ in both pastures.

Key words: Beef cattle. Carcass. Forage. Meat quality. Weight gain.

\section{Introduction}

Beef livestock production contributes decisively to the Brazilian agribusiness, being an activity of extreme importance in the social and economic scope. The soil and climate conditions, together with the location of a large part of the country in a tropical zone, where good conditions of temperature, luminosity and rainfall are present for a good part of the year, favor the use of tropical pastures in feeding animals, which is the most economical way to produce beef (FERRAZ; FELÍCIO, 2010), so that approximately $90 \%$ of the animals slaughtered in Brazil are finished on pasture (ANUALPEC, 2014).

There are several species of tropical grasses used for the formation of pastures in the country, especially those of the genera Panicum and Brachiaria. Research on tropical forages, evaluating production, chemical quality and animal performance are essential for the development of national livestock farming. In addition, the soil and climate differences and the presence of pests and diseases in the different regions of Brazil, make necessary the development and improvement of new plants, more adapted to these conditions.

Mulato II grass (CIAT 36087) is a new hybrid of Brachiaria, developed in Cali - Colombia, by the International Center of Tropical Agriculture (CIAT), originating from crosses between
Brachiaria ruziziensis and Brachiaria decumbens, with insertion of Brachiaria brizantha cv Marandu. Considering the need for forage resistant to the characteristics of climate and soil, the cultivar Mulato II appears to have an important attribute: tolerance to prolonged drought periods, up to six months in duration (ARGEL et al., 2007).

In relation to Marandu grass, factors such as low soil fertility requirement, spittlebug resistance and high productivity, under adequate management and fertilization conditions, made this grass one of the most used cultivars in pasture areas of the CentralWest and North Brazil (VALLE et al., 2009).

The development of forages with better nutritional quality and greater resistance to drought, as well as better adjustment of the stocking rate and better management of pasture areas, can minimize the effects of seasonality in production of the tropical forages, thus improving the national livestock development. This can lead to improved meat quality of slaughtered animals, mainly because they will be slaughtered younger (24-30 months) and with a good finishing ( $3 \mathrm{~mm}$ minimum).

In view of the above, this study aimed to compare the productive performance, carcass characteristics and meat quality of castrated male Nellore steers under rotational grazing in areas formed with Marandu grass and Convert grass. 


\section{Material and Methods}

The experiment was carried out from November $29^{\text {th }}, 2014$ to May $18^{\text {th }}, 2015$, at Figueira Farm and the Experimental Station Hildegard Georgina Von Pritzelwitz, located in the municipality of Londrina, State of Paraná, Brazil, with latitude 2334'25" South and longitude $50^{\circ} 58^{\prime} 17^{\prime \prime}$ 'West.

The climate of Londrina, according to the classification of Köppen, is Cfa, subtropical humid climate, with rainfall in all the seasons, with possible droughts in the winter period. The average temperature of the hottest month is usually above $25.5^{\circ} \mathrm{C}$ and that of the coldest month, below $16.4^{\circ} \mathrm{C}$ (IAPAR, 2016). The soil is structured eutrophic latosol (CAMARGO et al., 1987), but can also be classified as eutrophic red nitosol (EMBRAPA, 1999). Before the beginning of the experimental period, soil analysis and nutrient replacement were carried out in accordance with technical recommendations, aiming to standardize the entire experimental area.

The experimental area consisted of 40 ha, with 20 ha formed with Brachiaria spp cv. Mulato II and the other 20 ha with Brachiaria brizantha cv. Marandu. These two areas were subdivided into four modules of five ha each, called experimental units. These experimental units were then subdivided into five paddocks of one ha each, to facilitate the rotation of the animals within each unit. All the paddocks had access to drinking fountain and feeder, and animals had frequent access to the water and mineral supplement.

Steers were used for performance assessment and later for carcass and meat evaluations, and all procedures were approved by the ethics committee on the use of animals (CEUA 17445.2014.42).

Animal performance was evaluated in 80 castrated Nellore males with an initial age of approximately 22 months and an average weight of $330.75 \mathrm{~kg}$ body weight (BW). After initial weighing, the animals were already assigned to the respective paddock for adaptation from October $18^{\text {th }}, 2014$ until the start of the experiment on November $29^{\text {th }}$, 2014, when they weighed on average $352 \pm 36 \mathrm{~kg}$ body weight.

The animals were weighed at the beginning of the experimental period and every 28 days to control the sward height (adjustment in the stocking rate), body weight gain (BWG) and average daily gain (ADG) estimation. During the weighing, adjustments were made in the stocking rate. All weighings were performed after fasting for 16 hours, starting at 08:00 in the morning.

Compulsory vaccinations were carried out (footand-mouth disease) and against other diseases recommended in the regional mandatory calendar. The control of endo- and ectoparasites were performed according to the recommendations of the veterinarian.

The grazing method adopted was the rotational stocking with variable stocking rate (put-and-take), described by Mott and Lucas (1952), and each lot used five paddocks of the same plant species, with seven days of occupation and twenty and eight days of rest, during the period of intense growth of forage plants (spring and summer). After the adjustment, the animals occupied the due paddocks for seven days and were later relocated to the next paddock (same stocking), from where they left after a period of occupation of seven days. In the next paddock, after fourteen days, the process of adjusting the stocking was again performed.

The animals used to adjust the stocking rate remained on reserve pastures, consuming the same forage species used in the lot where they were inserted. Before entering the areas under evaluation, the animals were weighed to allow the calculation of the forage supply and stocking of the experimental areas, but were not used in the evaluation of animal performance.

At each fourteen days, at the time of entry and exit of the animals from the paddocks, samples 
were taken by cutting the pasture close to the ground with a square of $0.25 \mathrm{~m}^{2}(0.5 \mathrm{~m} \times 0.5 \mathrm{~m})$ to determine the production of forage mass present in each paddock ( $\mathrm{kg} / \mathrm{ha} \mathrm{DM})$. After collection, samples were sent to the laboratory located at Figueira Farm for proper weighing and separation of the structural components: leaf blade, stem + sheath and senescent material for subsequent drying in an oven at $55 \pm$ $5^{\circ} \mathrm{C}$ for 72 hours (SILVA; QUEIROZ, 2002). From this point, the values for the dry matter of leaf blades were obtained and, by estimation, the percentage and kilograms of leaf blades per hectare for later adjustment of stocking.

The stocking rate of pasture areas was determined from the production capacity of green leaves of each forage plant and the supply of forage defined for each season of the year (ALMEIDA et al., 2000). The adjustment of the stocking rate was done through the supply of forage defined during the evaluation of the production of forage materials, and the number of green leaf blades produced determined the number of animals used for stocking adjustment. On average, 6.19\% dry matter of green leaves was supplied for both treatments. This value varied according to the adjustment aiming to always offer $6 \%$ body weight of the animals in kilograms of dry matter of leaf blades $(2.5 \% \mathrm{BW}$, multiplied by $50 \%$ grazing efficiency and a surplus of $1 \% \mathrm{BW}$ ).

Samples were collected using the hand plucking technique in each paddock at 28-day intervals for subsequent pre-drying in an oven at $55 \pm 5^{\circ} \mathrm{C}$ for 72 hours (SILVA; QUEIROZ, 2002). Samples were milled in a Wiley mill (1 $\mathrm{mm}$ sieve) and then stored in identified plastic containers, oven-dried at $105^{\circ} \mathrm{C}$ for the determination of dry matter (DM). In addition, samples were analyzed for mineral matter (MM), organic matter (OM), crude protein (CP), neutral detergent fiber (NDF), acid detergent fiber (ADF) and lignin (LIG). The in vitro dry matter digestibility was determined according to the method of Tilley and Terry (1963), (Table 2).
At the end of the experimental period (168 days), the 80 steers were weighed after fasting for 16 hours and were taken to a slaughterhouse with Federal Inspection Service (SIF). Ten cattle from each replicate were slaughtered, totaling 80 animals. Of the 10 cattle of each repetition, the two heavier and the two lighter ones, were disregarded, using the 6 animals with intermediate weights per replicate for the analyses of carcass and meat, totaling 48 steers.

The slaughter was preceded by stunning following the humane slaughtering guidelines (BRASIL, 2000), with pneumatic penetration pistol. Bleeding occurred immediately after insensibilization by cutting large vessels. Carcasses were weighed after slaughter to measure hot carcass weight and hot carcass yield.

After 24 hours in a cold chamber at $2^{\circ} \mathrm{C}$, subjective evaluations of carcass conformation and finishing were carried out. Both were performed by means of photographic standards according to CE (2007). The final $\mathrm{pH}$ was determined 24 hours after the slaughter at the $12^{\text {nd }}$ rib in the Longissimus thoracis muscle of the left half carcass of each animal with the aid of a digital potentiometer with a Testo penetration probe. After $\mathrm{pH}$ measurement, the left half-carcasses were sectioned between the $12^{\text {nd }}$ and $13^{\text {rd }}$ ribs, where the subcutaneous fat thickness and the loin eye area were evaluated. These analyses were performed using a caliper (USDA, 1996). The loin eye area was outlined, between the $12^{\text {nd }}$ and $13^{\text {rd }}$ ribs, on vegetable paper with a thin tip pen, and the drawing obtained was used to estimate the loin area in square centimeters by means of a dot counting pattern (USDA, 1996).

Subsequently, a sample of each left half carcass, corresponding to the section between the $10^{\text {th }}$ and $12^{\text {nd }}$ ribs, was collected and weighed for posterior dissection and prediction of muscle, bone and adipose tissue proportions in the carcass according to the methodology proposed by Hankis and Howe (1946) adapted by Müller (1973). 
Meat quality was evaluated in the Longissimus thoracis muscle, corresponding to the section between the $10^{\text {th }}$ and $12^{\text {nd }}$ ribs. After removal of the muscle, it was sectioned in $3 \mathrm{~cm}$ thick samples. In the caudal-cranial direction, the first sample was used to analyze the meat color (value of $\mathrm{L}^{*}, \mathrm{a}^{*}, \mathrm{~b}^{*}$ and chroma), marbling (through photographic patterns, 1 to 12 - lowest to highest amount of marbling) (USDA, 1996) and water loss by pressure. The second and third samples were vacuum packed and frozen at $-18 \pm 2{ }^{\circ} \mathrm{C}$ for subsequent analysis of the shear force and chemical composition of the meat (dry matter, lipids, proteins and ashes), respectively.

Meat color was evaluated at three different points in the sample (muscle surface) by means of a Minolta ${ }^{\circledR}$ CR10 portable colorimeter for evaluation of the components L* (luminosity), a* (red-green component) and $\mathrm{b}^{*}$ (yellow-blue component) by the CIELAB system. With the values $\mathrm{a}^{*}$ and $\mathrm{b}^{*}$, chroma $\left(C^{*}\right)$ was calculated.

Water loss by pressure was determined by the technique described by Barbut (1996). Meat samples were weighed, placed between two filter papers and later placed between two acrylic boards. Afterwards, a weight of $10 \mathrm{~kg}$ was placed on the board for 5 minutes and then the sample was again weighed for the calculation of water loss by pressure by the difference between the final and the initial weight

To evaluate meat tenderness, shear force analysis was performed according to Whipple et al. (1990), with the Warner-Bratzler blade adapted in the Brookfield Texture Analyzer.
The analysis of the proximate composition (dry matter, lipids, proteins and ashes) of meat was performed according to AOAC (1990).

The design was completely randomized with two treatments (Marandu $x$ Convert) and four replications, in which the lot was the experimental unit for evaluation of animal performance. All data were tested for residuals normality and homogeneity of variances. Data were tested by analysis of variance using the statistical software $R$.

\section{Results and Discussion}

There was no significant difference in the mean forage dry matter production, percentage of leaf blades, dry matter production of leaf blades and stocking rate of the pastures composed of Marandu and Convert grasses (Table 1).

Together with the production data for the two grasses, there was also no significant difference for the chemical values between the two forages: dry matter, organic matter, mineral matter, crude protein, neutral detergent fiber, acid detergent fiber and lignin. However, values of in vitro dry matter digestibility of the Convert grass were $9.58 \%$ higher $(\mathrm{p}<0.05)$ than the Marandu grass (Table 2).

Higher values of in vitro dry matter digestibility of the Convert grass can provide a better performance of animals consuming it, because the higher digestibility value represents that a greater proportion of the ingested feed can be metabolized by the animal, resulting in better weight gain (CUNHA et al., 2007). 
Table 1. Mean values of forage dry matter production per hectare, percentage of leaf blades, dry matter production of leaf blades, stocking rate and supply of leaves of Marandu grass and Convert grass.

\begin{tabular}{lcccc}
\hline & $\begin{array}{c}\text { Brachiaria brizantha cv. } \\
\text { Marandu }\end{array}$ & $\begin{array}{c}\text { Brachiaria spp. cv. Mulato } \\
\text { II (Convert) }\end{array}$ & CV (\%) & P-Value \\
\hline Production (Kg/DM/ha) & 12632.74 & 10653.97 & 21.22 & 0.12577 \\
Leaf blades (\%) & 27.32 & 28.94 & 24.92 & 0.40767 \\
Production (Kg/DM/Leaf/ha) & 3117.79 & 2776.65 & 22.68 & 0.06275 \\
Stocking rate (AU/ha) & 3.20 & 2.88 & 20.31 & 0.07318 \\
\hline
\end{tabular}

CV - Coefficient of Variation; P-value - Probability; AU= Animal Unit.

Table 2. Mean values of dry matter (DM), organic matter (OM), mineral matter (MM), crude protein (PB), neutral detergent fiber (NDF), acid detergent fiber (ADF) and in vitro dry matter digestibility (IVDMD) of the leaf blades of Marandu grass and Convert grass.

\begin{tabular}{lcccc}
\hline & $\begin{array}{c}\text { Brachiaria brizantha cv. } \\
\text { Marandu }\end{array}$ & $\begin{array}{c}\text { Brachiaria spp. cv. Mulato } \\
\text { II (Convert) }\end{array}$ & CV (\%) & P-Value \\
\hline DM (\%NM) & 23.54 & 24.07 & 10.79 & 0.12639 \\
OM (\%DM) & 89.65 & 89.55 & 0.85 & 0.39673 \\
MM (\%DM) & 10.35 & 10.45 & 7.35 & 0.39673 \\
CP (\%DM) & 9.90 & 9.69 & 10.77 & 0.13686 \\
NDF (\%DM) & 67.76 & 64.69 & 4.57 & 0.18682 \\
ADF (\%DM) & 34.97 & 31.60 & 8.02 & 0.79445 \\
LIG (\%DM) & 2.52 & 2.00 & 21.73 & 0.69873 \\
IVDMD (\%) & 75.34 & 82.56 & 6.58 & $0.00731^{* *}$ \\
\hline
\end{tabular}

CV - Coefficient of Variation; P-value - Probability; (**) Significant for $(\mathrm{P}<0.01)$; NM - Natural Matter.

The average daily gain of animals during the experimental period was higher $(12.72 \%)$ for animals fed on pastures of Brachiaria spp. cv Mulato II (Convert) in relation to animals fed on pastures of Brachiaria brizantha cv. Marandu, being $0.682 \mathrm{~kg} /$ animal/day versus $0.605 \mathrm{~kg} /$ animal/day, respectively (Table 3). Possibly, the chemical quality of the leaf blades of the Convert grass (Table 2), whose mean IVDMD values were statistically superior (9.58\%) to the Marandu grass, was determinant in the average gain of the animals during the experimental period.

There was a difference $(\mathrm{p}<0.05)$ for the final body weight and hot carcass weight of the animals evaluated in this study (Table 3); those fed on pastures of Convert grass were $4.21 \%$ heavier than the animals fed on pastures of Marandu grass, with average weight of $470.45 \mathrm{~kg}$ and $451.43 \mathrm{~kg}$, respectively. For hot carcass weight, there was an increase of $3.26 \%$ for the animals that grazed the Convert grass in relation to those that grazed on Marandu grass, with $239.93 \mathrm{~kg}$ and 232.36 $\mathrm{kg}$, respectively (Table 3 ). These values show superiority of the Convert grass in relation to the average daily gain over the period since this gain influenced the slaughter weight of heavier animals with a higher hot carcass weight.

Nevertheless, there was no significant difference in carcass yield between the two treatments. Possibly, the fact that both treatments were from exclusively pasture-fed animals resulted in statistically similar carcass yields. According to McCurdy et al. (2010), 
the type of diet received by the animal (energy level) some of the factors that most influence the carcass and consequently the degree of carcass finishing are yield.

Table 3. Mean values of average daily gain (ADG), final body weight, hot carcass weight, carcass yield, carcass composition of steers on Marandu grass and Convert grass.

\begin{tabular}{lccccc}
\hline & $\mathrm{N}$ & Marandu & Convert & $\mathrm{CV}$ & P-Value \\
\hline ADG (Kg/animal/day) & 80 & 0.605 & 0.682 & 11.90 & $0.0000022^{* *}$ \\
Final body weight (Kg) & 80 & 451.43 & 470.45 & 5.09 & $0.00052^{* *}$ \\
Hot carcass weight (Kg) & 80 & 232.36 & 239.93 & 5.50 & $0.01105^{*}$ \\
Carcass yield (\%) & 80 & 51.47 & 51.00 & 2.33 & 0.08199 \\
Muscle (\%) & 48 & 60.18 & 59.60 & 4.82 & 0.49341 \\
Fat (\%) & 48 & 22.76 & 23.57 & 14.25 & 0.40458 \\
Bone (\%) & 48 & 17.04 & 16.88 & 5.99 & 0.58105 \\
\hline
\end{tabular}

$\mathrm{N}$ - Number of animals evaluated; CV - Coefficient of Variation; P-value - Probability; $(*)$ Significant for $(\mathrm{P}<0.05) ;(* *)$ Significant for $(\mathrm{P}<0.01)$.

There were no differences between treatments for carcass composition (percentage of muscle, fat and bone) (Table 3). It may be because all animals are of similar genetics composition, same age of slaughter (29 months), sexual class (castrated) and food base (forage). The carcass composition (bone/ fat/muscle ratio) can be influenced by the animal's age at slaughter, and their tissues present allometric growth, with initial development of nerve, bone, muscle tissues and finally adipose tissue. The development of the tissues is also influenced by the sexual class, where intact males present greater muscle development in relation to castrated males and females, and females present greater deposition of adipose tissue in relation to castrated males and intact males, with the same age and under the same feeding system (ROTTA et al., 2009).

The fat thickness and the loin eye area (Table 4) showed no significant differences $(p<0.05)$ between treatments. These results may have occurred because the animals evaluated had similar genetic origin and age. According to Pesonen and Huuskonen (2015), genetics is one of the factors that most influence these characteristics, in which animals from continental breeds have greater musculature and lower fat thickness in relation to animals of British origin. Zebu animals are in an intermediate zone of precocity in relation to the animals of continental origin (late) and the animals of British origin (precocious).

Besides these characteristics, the evaluations of marbling, conformation and finishing were also not influenced by the treatments (Table 4). Grade of finishing is subjective and influenced by age at slaughter, genetic group, sexual class and mainly by diet, where diets with higher energy densities usually raise this evaluation (MOREIRA et al., 2012). Carcass conformation is also a subjective measure and can be influenced mainly by the genetic group, sexual class, age at slaughter and nutrition. In turn, for meat marbling, there is a strong influence of the genetic group and diet, where animals of British origin (Bos taurus) and diets with high energy density provide greater deposition of intramuscular fat (BONIN et al., 2015).

The result that marbling, conformation and finishing evaluations were statistically similar could have occurred because animals of both treatments had similar genetic group, age at slaughter and sexual class, and were also not fed diets with high energy density. 
Both treatments resulted in good finishing and fat thickness (3.72 $\mathrm{mm}$ and $3.80 \mathrm{~mm}$ fat), since the desired value by the meat industry is 3.00 $\mathrm{mm}$ subcutaneous fat. This demonstrates that it is possible to finish animals on pasture, without protein or energy supplements and with less than 30 months old. The fact that the animals are castrated, corroborated this fact.

Table 4. Mean values of fat thickness, muscle length, loin eye area, marbling, conformation and finishing of steers on Marandu grass and Convert grass.

\begin{tabular}{lccccc}
\hline & $\mathrm{N}$ & Marandu & Convert & CV & P-Value \\
\hline Fat thickness $(\mathrm{mm})$ & 48 & 3.72 & 3.80 & 41.65 & 0.85782 \\
Loin eye area $\left(\mathrm{cm}^{2}\right)$ & 48 & 69.04 & 70.68 & 9.27 & 0.39506 \\
Marbling & 48 & 1.88 & 2.22 & 38.99 & 0.14759 \\
Conformation & 48 & 8.75 & 10.42 & 30.24 & 0.05230 \\
Finishing & 48 & 5.04 & 5.50 & 26.38 & 0.25948 \\
\hline
\end{tabular}

$\mathrm{N}$ - Number of animals evaluated; CV - Coefficient of Variation; P-value - Probability; Marbling $1=$ Absent; $12=$ In excess. Carcass conformation 1, 2, $3=$ Poor; 4, 5, $6=$ Intermediate; 7, 8, $9=$ Good; 10, 11, 12= Very Good; 13, 14, 15= Excellent; 16, 17, $18=$ Superior. Each class was subdivided into three subpositions.

Carcass finishing 1, 2, $3=$ Poor; 4, 5, $6=$ Slight; 7, 8, $9=$ Intermediate; 10, 11, $12=$ Strong; 13, 14, $15=$ Very strong. Each class was subdivided into three subpositions.

Values of final $\mathrm{pH}$ and water loss by pressure showed no significant difference between treatments (Table 5). The fact that the final $\mathrm{pH}$ values are similar and according to the ideal (below 5.9) could have occurred because all animals were castrated. In agreement with Weglarz (2011), the post-mortem meat $\mathrm{pH}$ considered as normal is in the range of 5.4 and 5.8. According to Kuss et al. (2010), castration may decrease the effects of pre-slaughter stress. Consequently, water loss by pressure was also not influenced since it is related to the final $\mathrm{pH}$ of the meat.

Table 5. Mean values of final $\mathrm{pH}$, water loss by pressure, shear force (SF), color and chemical composition of meat from steers fed on Marandu grass and Convert grass.

\begin{tabular}{|c|c|c|c|c|c|}
\hline & $\mathrm{N}$ & Marandu & Convert & C.V. & P-value \\
\hline Final $\mathrm{pH}$ & 48 & 5.57 & 5.59 & 1.60 & 0.38566 \\
\hline Water loss by pressure (\%) & 48 & 28.84 & 28.41 & 7.63 & 0.49846 \\
\hline SF (kgf) & 48 & 10.03 & 8.90 & 23.51 & 0.0895 \\
\hline Value of $\mathrm{L}^{*}$ & 48 & 35.04 & 36.00 & 3.98 & $0.02494 *$ \\
\hline Value of $a^{*}$ & 48 & 14.28 & 15.30 & 12.15 & 0.05857 \\
\hline Value of $b^{*}$ & 48 & 9.64 & 10.28 & 9.36 & $0.02246^{*}$ \\
\hline Value of $C^{*}$ & 48 & 17.24 & 18.45 & 10.35 & $0.02970 *$ \\
\hline Crude Protein (\%) & 48 & 21.14 & 21.15 & 3.45 & 0.96225 \\
\hline Moisture (\%) & 48 & 74.55 & 74.71 & 2.72 & 0.44896 \\
\hline Ether extract (\%) & 48 & 1.28 & 1.36 & 29.62 & 0.50599 \\
\hline Ash $(\%)$ & 48 & 1.00 & 1.01 & 5.95 & 0.8684 \\
\hline
\end{tabular}

N - Number of animals evaluated; CV - Coefficient of Variation; P-value - Probability; (*) Significant for $(\mathrm{P}<0.05)$. 
There was also no significant difference in the shear force of beef from steers fed on pastures of Marandu grass or Convert grass, with values of $10.03 \mathrm{~kg}$ and $8.90 \mathrm{~kg}$, respectively. Both values are considered high for the tenderness standard for beef. According to Shackelford et al. (1991), the limit of a meat considered tender is $4.6 \mathrm{~kg}$ and values above that make the meat to be considered tough. Collagen solubility and consequently meat tenderness can be influenced by the growth rate, type and composition of the feed, animal management, age at slaughter, physical activity and the muscle to be analyzed (ARCHILE-CONTRERAS et al., 2010).

There was a difference $(p<0.05)$ for the meat color values. Animals fed on pastures of Convert grass showed higher values of luminosity $\left(\mathrm{L}^{*}\right)$, yellow intensity $\left(b^{*}\right)$ and chroma $\left(C^{*}\right)$ in relation to the animals fed on pastures of Marandu grass (Table 5). There was no significant difference for the values of red intensity between the two treatments.

These values are in accordance with the description of Muchenjea et al. (2009) for beef color, where the mean values of luminosity $\left(\mathrm{L}^{*}\right)$ ranged from 33.2 to 41.0 , red color ( $\mathrm{a}^{*}$ ) varied from 11.1 to 23.6 and the yellow color $\left(b^{*}\right)$ varied between 6.1 and 11.3. These authors affirm that the luminosity value of the meat $\left(\mathrm{L}^{*}\right)$, that is the meat's ability to reflect incident light, can be influenced by several factors, such as diet, age, physical activity, quantity of pigments, amount of fat and final $\mathrm{pH}$. However, the values of $\mathrm{a}^{*}$ reflect the amount of red pigment of myoglobin and cytochrome $\mathrm{C}$ while the values of $b^{*}$ are related to the concentration of pigments such as carotenes and xanthophylls (HEDRICK et al., 1983).

There was no difference $(\mathrm{P}<0.05)$ for the chemical composition of beef from steers fed on pastures of Marandu grass and Convert grass (Table 5). Possibly, these values were similar because both treatments have animals of the same genetics composition, sexual class and age.
Values of moisture, crude protein and ash are in agreement with Rossato et al. (2010), who worked with 36-month-old Nellore steers on pasture and obtained values of $73.64 \%, 21.50 \%$ and $0.95 \%$, respectively. The present study also obtained results similar to those of Lopes et al. (2012) and Pitombo et al. (2013), the first working with feedlot Nellore bulls, obtained moisture, $\mathrm{CP}$ and ash values of $74.2 \%, 21.9 \%$ and $1.0 \%$, respectively. In turn, Pitombo et al. (2013) worked with Nellore X Guzerá bulls and reported values of moisture, EE and ash of $75.34 \%, 1.44 \%$ and $1.04 \%$, respectively.

\section{Conclusion}

It is possible to finish castrated young steers (up to 30 months) with subcutaneous fat thickness required by industry (minimum of $3 \mathrm{~mm}$ ) on pastures of Brachiaria brizantha cv. Marandu and Brachiaria spp. cv. Mulato II (Convert). Animals finished on pastures of Brachiaria spp. cv. Mulato II (Convert) reached better average daily gain, higher slaughter and carcass weights, in relation to the animals finished on pastures of Brachiaria brizantha cv. Marandu.

\section{Acknowledgement}

To DOW Agrosciences, FEALQ and CAPES for making resources available to conduct this work.

\section{References}

ALMEIDA,E.X.; MARASCHIN, G.E.; HARTHMANN, O. E. L.; RIBEIRO FILHO, H. M. N.; SETELICH, E. A. Oferta de forragem de Capim-Elefante Anão Mott e o rendimento animal. Revista Brasileira de Zootecnia, Viçosa, MG, v. 29, n. 5, p. 1288-1295, 2000.

ANUÁRIO DA PECUÁRIA BRASILEIRA ANUALPEC. Integração lavoura-pecuária pode começar pelo pasto. São Paulo: Informa Economics FNP, 2014.

ARCHILE-CONTRERAS, A. C.; MANDELL, I. B.; PURSLOW, P. P. Disparity of dietary effects on collagen characteristics and toughness between two beef muscles. Meat Science, Barking, v. 86, n. 2, p. 491-497, 2010. 
ARGEL, P. J.; MILES, J. W.; GUIOT, J. D.; CUADRADO, H.; LASCANO, C. E. Cultivar Mulato II (Brachiaria híbrida CIAT 36087) gramínea de alta qualidade $e$ produção forrageira, resistente a cigarrinhas e adaptada a solos tropicais ácidos. Cali: CO. Centro Internacional de Agricultura Tropical (CIAT), 2007. 22 p.

ASSOCIATION OF OFFICIAL ANALYTICAL CHEMISTS - AOAC. Official methods of analysis. Arlington: AOAC International, 1990. 1117 p.

BARBUT, S. Estimates and detection of the PSE problem in young turkey breast meat. Canadian Journal of Animal Science, Sherbrooke, v. 76, n. 3, p. 455-457, 1996.

BONIN, M. de N.; FERRAZ, J. B. S.; PEDROSA, V. B.; LUZ E SILVA, S. da; GOMES, R. C.; CUCCO, D. C.; SANTANA, M. H. A.; CAMPO, J. H. A.; BARBOSA, V. N.; CASTRO, F. S. F.; NOVAIS, F. J.; OLIVEIRA, E. C. M. Visual body-scores selection and its influence on body size and ultrasound carcass traits in Nellore cattle. Journal of Animal Science, Champaign, v. 93, n. 12, p. 5597-5606, 2015.

BRASIL. Ministério da Agricultura, Pecuária e Abastecimento. Instrução Normativa n. 3, de 17 de Janeiro de 2000. Regulamento técnico de métodos de insensibilização para o abate humanitário de animais de açougue. Diário Oficial [da] União, Brasília, DF, 24 jan, 2000, Seção 1. p. 14.

CAMARGO, M. N.; KLAMT, E.; KAUFFMAN, J. H. Classificação de solos usado em levantamentos pedológicos no Brasil. Boletim Informativo da Sociedade Brasileira do Solo, Campinas, v. 12, n. 1, p. 11-33, 1987.

COMUNIDADE EUROPEIA - CE. Regulamento $\mathrm{n}^{\circ}$ 1234/2007 do Conselho de 22 de Outubro de 2007, que estabelece uma organização comum dos mercados agrícolas e disposições específicas para certos produtos agrícolas. Jornal Oficial da União Europeia $n^{\circ}$ L 299/95 de 16 de novembro de 2007. p. 1. Disponível em: $<$ https://publications.europa.eu/pt/publication-detail/-/ publication/1427209b-e370-4343-a5e7-cfdbccede4e4/ language-pt $>$. Acesso em: 20 apr. 2018.

CUNHA, F. F.; SOARES, A. A.; PEREIRA, O. G.; MANTOVANI, E. C.; SEDIYAMA, G. C.; ABREU, F. V. S. Comparação bromatológica e digestibilidade in vitro da matéria seca do capim-tanzânia irrigado. Bioscience Journal, Uberlândia, v. 23, n. 2, p. 25-33, 2007.

EMBRAPA. EMPRESA BRASILEIRA DE PESQUISA AGROPECUÁRIA. Centro Nacional de Pesquisa de Solos. Sistema brasileiro de classificação de solos. Brasília: Embrapa. Produção de Informações; Rio de Janeiro: Embrapa Solos 1999. 412 p.
FERRAZ, J. B. S.; FELÍCIO, P. E. Production systems an example from Brazil. Meat Science, Oxford, v. 84, n. 2, p. 238-243, 2010.

HANKINS, O. G.; HOWE, P. E. Estimation of the composition of beef carcasses and cuts. Washington, D.C. (Tech. Bulletin - USDA, 926). 1946. 20 p.

HEDRICK, H. B.; PATERSON, J. A.; MATCHES, A. G.; THOMAS, J. D.; MORROW, W. G.; LIPSEY, R. J. Carcass and palatability characteristics of beef produced on pasture, corn silage and corn grain. Journal of Animal Science, Champaign, v. 57, n. 4, p. 791-801, 1983.

INSTITUTO AGRONÔMICO DO PARANÁ - IAPAR. Cartas climáticas do Paraná. Londrina. 2016. Disponível em: <http://www.iapar.br/modules/conteudo/conteudo. php? conteudo=677>. Acesso em: 20 dez. 2016.

KUSS, F.; LÓPEZ, J.; RESTLE, J.; BARCELLOS, J. O. J.; MOLLETA, J. L.; PAULA-LEITE, M. C. Qualidade da carne de novilhos terminados em confinamento e abatidos aos 16 ou 26 meses de idade. Revista Brasileira de Zootecnia, Viçosa, MG, v. 39, n. 4, p. 924-931, 2010.

LOPES, L. S.; LADEIRA, M. M.; MACHADO NETO, O. R.; RAMOS, E. M.; PAULINO, P. V. R.; CHIZZOTTI, M. L.; GUERREIRO, M. C. Composição química e de ácidos graxos do músculo longissimus dorsi e da gordura subcutânea de tourinhos Red Norte e Nelore. Revista Brasileira de Zootecnia, Viçosa, MG, v. 41, n. 4, p. 978 985, 2012.

McCURDY, M. P.; KREHBIEL, C. R.; HORN, G. W.; LANCASTER, P. A.; WAGNER, J. J. Effects of winter growing program on visceral organ mass, composition, and oxygen consumption of beef steers during growing and finishing. Journal of Animal Science, Champaign, v. 88, n. 4, p. 1554-1563, 2010.

MOREIRA, P. S. A.; BERBER, R. C. A.; LOURENÇO, F. J.; BELUFI, P. R.; KONRAD, M. Efeito do sexo e da maturidade sobre o peso de carcaça quente, acabamento e conformação de bovinos abatidos em Sinop-MT. Comunicata Scientiae, Teresina, v. 3, n. 4, p. 292-298, 2012.

MOTT, G. O.; LUCAS, H. L. The desing, conduct, and interpretation of grazing trials on cultivated and improved pastures. In: INTERNATIONAL GRASSLAND CONGRESS, 6., 1952, Pennsylvania. Proceedings... Pennsylvania: State College Press, 1952. p. 1380-1385.

MUCHENJEA, V.; DZAMAC, B. K.; CHIMONYOA, M.; STRYDOM, P. E.; HUGO, A.; RAATS, J. G. Some biochemical aspects pertaining to beef eating quality and consumer health: a review. Food Chemistry, Oxford, v. 112 , n. 2, p. 279-289, 2009. 
MÜLLER, L. Técnicas para determinar la composición de la canal. Guadalajara: Memoria de la Asociación Latinoamericana de Producción Animal, 1973. 75 p.

PESONEN, M.; HUUSKONEN, A. Production, carcass characteristics and valuable cuts of beef breed bulls and heifers in Finnish beef cattle population. Agricultural and Food Science, Helsinki, v. 24, n. 3, p. 164-172, 2015.

PITOMBO, R. S.; SOUZA, D. D. N.; RAMALHO, R. O. S.; FIGUEIREDO, A. B. A.; RODRIGUES, V. C; FREITAS, D. D. G. C.; FERREIRA, J. C. S. Qualidade da carne de bovinos superprecoces terminados em confinamento. Arquivo Brasileiro de Medicina Veterinária e Zootecnia, Belo Horizonte, v. 65, n. 4, p. 1203-1207, 2013.

ROSSATO, L. V.; BRESSAN, M. C.; RODRIGUES, E. C.; GAMA, L. T.; BESSA, R. J. B.; ALVES, S. P. A. Parâmetros físico-químicos e perfil de ácidos graxos da carne de bovinos Angus e Nelore terminados em pastagem. Revista Brasileira de Zootecnia, Viçosa, MG, v. 39, n. 5, p. 1127-1134, 2010.

ROTTA, P. P.; PRADO, R. M.; PRADO, I. N.; VALERO, M. V.; VISENTAINER, J. V.; SILVA, R. R. The effects of genetic groups, nutrition, finishing systems and gender of Brazilian cattle on carcass characteristics and beef composition and appearance: a review. AsianAustralasian Journal of Animal Science, Seoul, v. 22, n. 12, p. 1718-1734, 2009.
SHACKELFORD, S. D.; KOOHMARAIE, M.; MILLER, M. F.; CROUSE, J. D.; REAGAN, J. O. An evaluation of tenderness of the longissimus muscle of Angus by Hereford versus Brahman crossbred heifers. Journal of Animal Science, Champaign, v. 69, n. 1, p. 171-177, 1991.

SILVA, D. J.; QUEIROZ. A. C. Análise de alimentos: métodos químicos e biológicos. 2. ed. Viçosa, MG: UFV, 2002. $178 \mathrm{p}$.

TILLEY, J. M. A.; TERRY, R. A. A two-stage technique for the in vitro digestion of forage crops. Journal of British Grassland Society, Oxford, v. 18, n. 2, p. 104111, 1963.

\section{UNITED STATES DEPARTMENT OF} AGRICULTURE - USDA. Official United States Standards for Grades of Carcass Beef. Washington: Agriculture Marketing Service, 1996.

VALLE, C. B.; JANK, L.; RESENDE, R. M. S. O melhoramento de forrageiras tropicais no Brasil. Revista Ceres, Viçosa, MG, v. 56, n. 4, p. 460-472, 2009.

WEGLARZ, A. Effect of pre-slaughter housing of different cattle categories on beef quality. Animal Science Papers \& Reports, Jastrzębiec, v. 29, n. 1, p. 43-52, 2011.

WHIPPLE, G.; KOOHMARAIE, M.; DIKEMAN, M. E. CROUSE, J. D.; HUNT, M. C.; KLEMM, R. D. Evaluation of attributes that affect longissimus muscle tenderness in Bos taurus and Bos indicus cattle. Journal of Animal Science, Champaign, v. 68, n. 9, p. 2716-2728, 1990. 
